\title{
Wheat Productivity and Marginal Analysis of Evapotranspiration Production Functions under Deficit Irrigation across Sowing Dates in Eastern India
}

\author{
Swaraj Kumar Dutta ${ }^{*}$, Pramiti Kumar Chakraborty ${ }^{2}$, Swapan Kumar Mukhopadhyay $^{3}$, \\ Rajib Nath $^{3}$ and Prodip Kumar Chakraborty ${ }^{2}$ \\ ${ }^{1}$ Department of Agronomy, Bihar Agricultural University, Sabour, Bihar, India \\ ${ }^{2}$ Department of Agril. Meteorology and Physics, Faculty of Agriculture, Bidhan Chandra Krishi \\ Viswavidyalaya, Mohanpur, West Bengal, India \\ ${ }^{3}$ Department of Agronomy, Bidhan Chandra Krishi Viswavidyalaya, Mohanpur, India \\ *Corresponding author
}

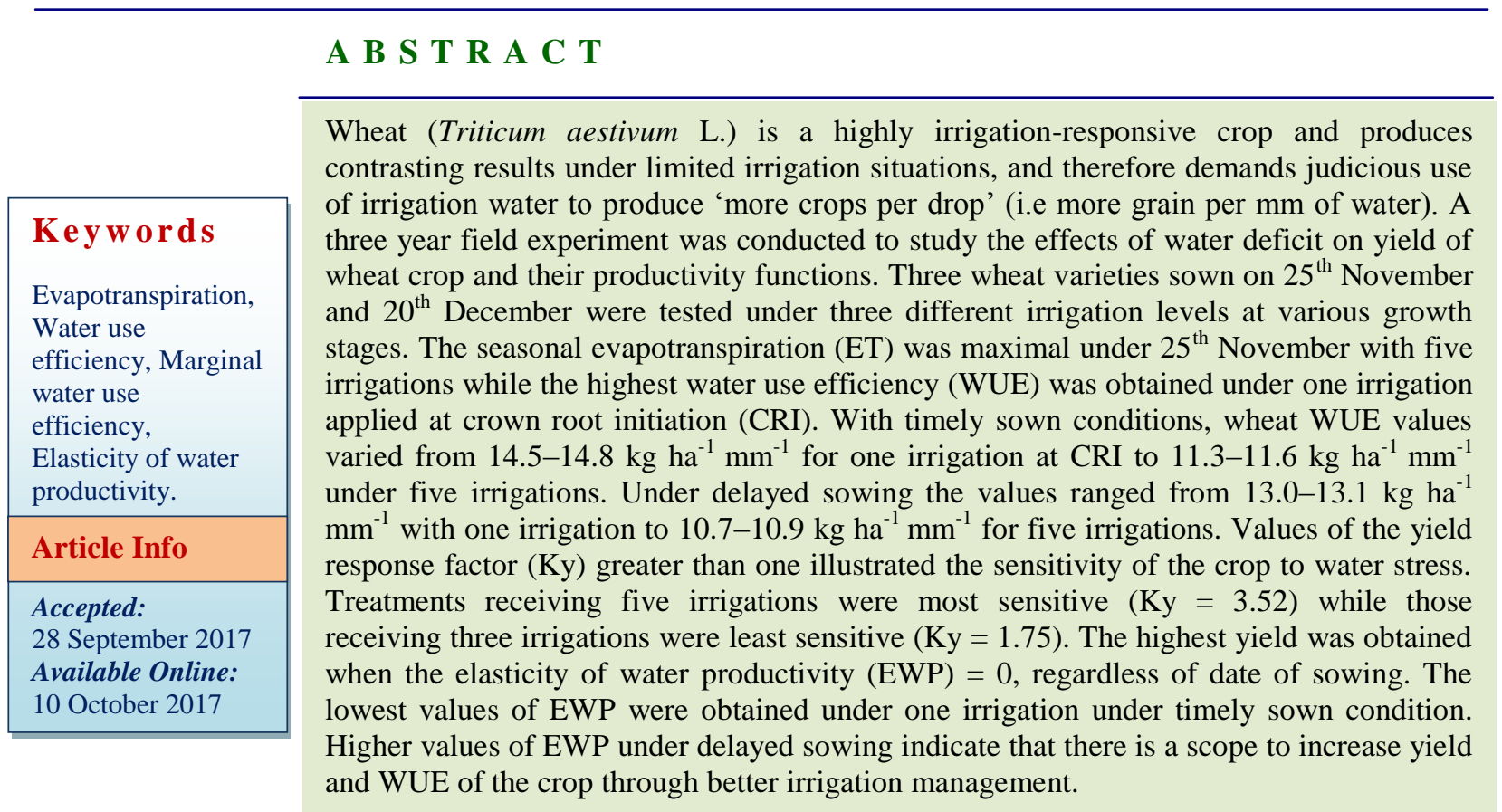

\section{Introduction}

Wheat (Triticum aestivum L.) is an important food crop in India and is cultivated over an area of 31.2 million hectares with an annual production of 95.9 million tonnes. In West Bengal wheat is grown on an area of 0.34 million hectares with an annual production of 0.95 million tonnes and average yields of 2.8 t/ha. Wheat is sown either as a rainfed or an irrigated crop but $96 \%$ area of the crop in West Bengal is irrigated (Directorate of Economics and Statistics, 2014). The sowing time for wheat crop ranges from first fortnight of November for timely sowing to $2^{\text {nd }}$ fortnight of December for late sowing (DWR, 2007). Late transplanting of rice along with shifting rainfall patterns often delay wheat 
sowing because of high soil moisture content during the early part of November. To gain higher yields farmers tend to irrigate the wheat crop by pumping groundwater resources. Although the water supply is often inadequate and the crop is widely grown under limited irrigation and under such circumstances the water stressed crop maybe highly responsive to irrigation water. The crop water production functions quantify the effect of irrigation on crop production which relate crop yield to amount of water applied (Sun et al., 2006). Understanding the effect of water stress on yield is essential for planning a suitable irrigation strategy for wheat.

Wheat is sensitive to water stress and therefore needs frequent irrigation for optimal growth and yield (Alderfasi and Nielsen 2001). Under normal conditions, 4-6 irrigations are recommended for optimal wheat production in India (Singh, 1991). Reduced irrigation increases WUE of wheat (Xue et al., 2006) but if the crop is overstressed, reduced photosynthesis and accelerated leaf senescence may reduce the yield (Kobata et al., 1992). The crop water production (CWP) function expresses the relationship between yield and the total amount of water input (Doorenbos and Kassam 1979) and is useful for water management applications. However, change in crop yield is attributed to different transpiration rates (Olesen et al., 2000). Thus, the more useful production function form is the evapotranspiration production function (ETPF) which describes the relationship between yield and seasonal ET. The empirical coefficients vary with climate, crop type, variety, irrigation, soil texture, fertiliser and tillage methods (Mandal et al., 2005). Many researchers have deduced a linear relationship between yield and ET (Musick et al., 1994; Zhang and Oweis 1999) although Kang et al., (2002) showed that the relationship between ET and yield can be best described by quadratic functions. A non-linear crop response may occur when increased irrigation frequency results in increased ET without a corresponding increase in yield. In field studies with wheat, barley (Hordeum vulgare L.), and sugarcane (Saccharum officinarum), Gulati and Murty, 1979 reported yield to be a quadratic function of ET. The yield response factor (Ky) captures the complex linkages between production and water use by a crop and describes the relationship between relative yield reduction due to corresponding relative ET reduction (Doorenbos and Kassam 1979). Crops having $\mathrm{Ky}<1$ are more tolerant to water deficit compared to crops with $\mathrm{Ky}>1$, in which the crops are more sensitive to water deficit, resulting in larger yield reductions with reduced water availability due to stress.

Although limited studies for linear ETPFs are available, studies relating Ky with yield, ET and WUE with respect to a quadratic $\mathrm{Y}$ and ET relationship for Eastern India are not available. It is also necessary to understand the elasticity of water productivity (EWP, defined as the percent change in yield to the percent change in ET) with respect to a nonlinear ETPF and the effect of irrigation levels and dates of sowing on the marginal analysis of crop water production functions. These relationships will assist researchers and producers in the determination of optimal combinations of planting and water management strategies with the goal of increasing WUE and crop productivity for a given area. The objective of this study is to discuss the effects of dates of sowing and irrigation on ET of wheat varieties and determine the relationship between ET and wheat grain yield for Eastern India through crop water production functions.

\section{Materials and Methods}

\section{Experimental site}

The experiment was conducted at the District Seed Farm of the Bidhan Chandra Krishi 
Viswavidyalaya, Kalyani $\left(22^{0} 56^{\prime} \mathrm{N}, 88^{0} 32^{\prime}\right.$ E, $9.75 \mathrm{~m}$ above sea level), West Bengal, Eastern India. The experimental site experiences a tropical humid climate. The soil is loamy in texture and classified as an Entisol (subgroup: Typic Fluvaquent) as per the USDA modern taxonomical classification. The soil was neutral in reaction. The hydrophysical and chemical properties of the soil are presented in Table 1. The field experiments were conducted during the winter seasons (November-April) of 2009-10, 201011 and 2011-12. The mean annual rainfall is $1457 \mathrm{~mm}$ (average of 30 years), 90\% of which is received between June and September. The rainfall received during the crop growth period of wheat (Triticum aestivum L.) was 45.2, 153.1 and $112.8 \mathrm{~mm}$ for 2009-10, 2010-11 and 2011-12 respectively. During the first two study years 83 and $86 \%$ of the rainfall occurred during grain filling, while during the third year $61 \%$ of the rainfall occurred during vegetative growth. The minimum (January) and maximum (April) monthly average temperatures were $16.5-18.4{ }^{\circ} \mathrm{C}$ and $23.3-$ $26.7^{\circ} \mathrm{C}$, respectively. The cumulative monthly pan evaporation was minimal during December and maximal during April (Fig. 1).

\section{Experimental treatments}

The experiment comprised of 18 treatment combinations with two dates of sowing, three irrigation levels, and three wheat cultivars. The design was a split-split-plot randomized complete block design with three replications. The dates of sowing each year were 25 November $\left(D_{1}\right)$ and 20 December $\left(D_{2}\right)$. Irrigation treatments were as follows: one irrigation at crown root initiation (CRI) 20-25 days after sowing (DAS) $\left(\mathrm{I}_{1}\right)$; three irrigations with one at CRI, one at tillering (45-50 DAS), and one at boot stage (80-85 DAS) $\left(\mathrm{I}_{2}\right)$; five irrigations with one at CRI, one at tillering, one at jointing (65-70 DAS), one at boot stage and one at milk stage (100-105 DAS) $\left(\mathrm{I}_{3}\right)$. Irrigation water was applied through a check basin in the experimental plots. The depth of water applied for each irrigation was $60 \mathrm{~mm}$ during the different growth stages of wheat. The volume of water was measured from discharge of the shallow tubewell and time to application, which was predetermined at the beginning of every season. Three prominent wheat cultivars PBW -343 $\left(\mathrm{V}_{1}\right), \mathrm{K}-307\left(\mathrm{~V}_{2}\right)$ and RSP- $561\left(\mathrm{~V}_{3}\right)$ were assigned to the subsub plots. These varieties are widely grown in North Eastern Plain Zone of India (DWR, 2007) and are of medium duration (120-125 days). Each plot measured $16.56 \mathrm{~m}^{2}(2.07 \mathrm{~m} \times$ $8 \mathrm{~m})$. Wheat was planted with a row spacing of $23 \mathrm{~cm}$ and was fertilized with 120-60-40 $\mathrm{kg}$ nitrogen $(\mathrm{N})$, phosphorus $\left(\mathrm{P}_{2} \mathrm{O}_{5}\right)$ and potash $\left(\mathrm{K}_{2} \mathrm{O}\right)$ per hectare as urea, single super phosphate and muriate of potash respectively.

\section{Calculations}

Grain yield was recorded on a dry weight basis at $12 \%$ moisture content from the net plot harvest and the yield components were recorded from a subsample of $100 \mathrm{~cm}$ rows in each replication.

Seasonal evapotranspiration (ET) was estimated using the water balance approach,

$\mathrm{ET}=\mathrm{P}+\mathrm{I}+\mathrm{C}-\mathrm{DP}-\mathrm{R}-\Delta \mathrm{S}(1)$

Where, $\mathrm{P}$ is the precipitation; $\mathrm{I}$ is irrigation; $\mathrm{C}$ is capillary contribution; DP is deep percolation; $\mathrm{R}$ is runoff and $\Delta \mathrm{S}$ is the change in soil water storage. Since the depth of groundwater was deep (fluctuating within 0.8 to $1.5 \mathrm{~m}$, (Bandyopadhyay and Mallick 2003), contribution through capillary rise was assumed negligible. A negligible change in soil moisture storage below $60 \mathrm{~cm}$ soil depth was observed so deep percolation was considered negligible. Runoff from the field was considered insignificant since all plots 
were bunded. Soil moisture extraction from $0-15,15-30,30-45$ and 45-60 cm soil depths was measured gravimetrically and computed according to Eqn. 2:

$\left[\sum_{\mathrm{i}=1}^{\mathrm{n}} \frac{M b i-M e i}{100}\right] \times B D_{\mathrm{i}} \times D_{\mathrm{i}}(2)$

where, $\mathbf{M}_{\mathrm{bi}}$ is the soil moisture percentage before irrigation; $\mathrm{M}_{\mathrm{ei}}$ is the soil moisture percentage after irrigation; $n$ is the number of soil layers considered in root zone depth $\left(D_{i}\right)$ and $\mathrm{BD}_{\mathrm{i}}$ is the bulk density of $\mathrm{i}^{\text {th }}$ soil layer. However for the treatments having one and three irrigations, the changes in soil profile water storage was measured gravimetrically (profile water storage between two consecutive soil water measurements, expressed in $\mathrm{mm}$ ), at 15 days interval, besides irrigation instances and rainfall events.

Factors other than water were considered nonlimiting. Therefore, yield and ET were both considered functions of water availability. ETPFs were derived from the quadratic relationship between measured yield and seasonal ET represented as:

$\mathrm{Y}=\mathrm{a}+\mathrm{b} \mathrm{ET}+\mathrm{c} \mathrm{ET}^{2}(3)$

In the case of quadratic functions between yield (Y) and evapotranspiration (ET), both the intercept (a) and coefficient (c) are generally negative (Liu et al., 2002). The term, "elasticity" is a measure of how responsive a variable is to the change in another variable. This can be quantified as the ratio of the change in one variable to the change in another variable, when the latter variable has a causal influence on the former. Thus the ratio of MWUE to WUE can be viewed as the elasticity of water productivity (EWP), which provides a means to compare the relative change in yield with the relative change in ET (Liu et al., 2002) -

$\mathrm{EWP}=\frac{\mathrm{NWUE}}{\mathrm{WUE}}=\frac{\mathbb{( d Y / Y )}}{(\mathrm{dET} / \mathrm{ET})}(4)$
The elasticity is not constant for the entire production function. Thus Liu et al., (2002) proposed the WUE, MWUE and EWP to be as follows -

$\mathrm{WUE}=(\mathrm{a} / \mathrm{ET})+\mathrm{b}+(\mathrm{c} \times \mathrm{ET})(5)$

MWUE $=b+(2 \times c \times E T)(6)$

$\mathrm{EWP}=\frac{[(b \times \mathrm{ED})+(2 \times c \times \mathrm{ED}]]}{[\mathrm{a}+(\mathrm{b} w \mathrm{ED})+(\mathrm{c} \times \mathrm{ED})]}(7)$

MWUE will decrease linearly with increasing ET. WUE will reach its maximum when ET = $(\mathrm{a} / \mathrm{c})^{1 / 2}$ while the crop yield will be maximum when $\mathrm{ET}=-\mathrm{b} /(2 \times \mathrm{c})$.

The relative yield decrease described by (Doorenbos and Kassam 1979) is as follows -

$\left(1-\frac{Y_{a}}{Y_{m}}\right)=K_{Y}\left(1-\frac{E T_{a}}{E T_{m}}\right)$

Where, Ya and ETa correspond to the actual yield and actual ET, respectively, and Ym and ETm are the maximum yield and maximum ET attainable for the crop grown under optimal agronomic conditions, respectively. Under such situations Liu et al., (2002) represented the yield response factor $(\mathrm{Ky})$ as-

$K_{y}=\frac{\left(-\mathrm{c} x \mathrm{ET}^{2}\right)}{\mathrm{Y}_{\mathrm{m}}}(9)$

Significant effects were identified by analyses of variance (SAS 9.3) using PROC MIXED, holding irrigation, date of sowing, variety, and their interactions as fixed effects. Replication and replication by variety interactions were considered random effects. Effects were considered significant if $p<0.05$ unless otherwise stated. Means and standard errors of the means were obtained using PROC MEANS. Multiple pairwise means separation tests were conducted using the Tukey Honestly Significant Difference test at the $95 \%$ confidence level with the \%PDMIX800 macro (Saxton, 1998). 
Regression relationships were determined using the data analysis tool pack of MicrosoftExcel.

\section{Results and Discussion}

Response of seasonal evapotranspiration (ET) to different irrigation levels and dates of sowing

Seasonal evapotranspiration (ET) was different with different treatment combinations. The seasonal ET of wheat (Triticum aestivum L.) averaged across varieties, with one irrigation $\left(\mathrm{I}_{1}\right)$ ranged within 165.5 - $182.7 \mathrm{~mm}$ under $\mathrm{D}_{1}$ sowing and 161.9 - $179.6 \mathrm{~mm}$ under $\mathrm{D}_{2}$ sowing (Table 2). These values were closely related to the amounts of rainfall registered during the three cropping seasons. Under $\mathrm{I}_{2}$ the seasonal ET values ranged between 229.8$254.0 \mathrm{~mm}$ and $215.2-244.9 \mathrm{~mm}$ for $\mathrm{D}_{1}$ and $\mathrm{D}_{2}$ sown crops respectively. $\mathrm{I}_{3}$ seasonal ET values varied between $319.6-333.6 \mathrm{~mm}$ and 295.0-304.8 $\mathrm{mm}$ for $\mathrm{D}_{1}$ and $\mathrm{D}_{2}$ sown crops respectively. During the three cropping years, 2010-11 registered the lowest seasonal ET values in all irrigation treatments.

The seasonal ET was 67.3-93.1 \% and 22.7$39.1 \%$ higher with five irrigations $\left(I_{3}\right)$ compared to the $\mathrm{I}_{1}$ and $\mathrm{I}_{2}$ levels of irrigation, respectively. Seasonal ET was higher under timely sowing $\left(D_{1}\right)$ and decreased considerably in late sown crop $\left(\mathrm{D}_{2}\right)$. For timely sowing $\left(\mathrm{D}_{1}\right)$, ET was $2-3 \%$ higher under $I_{1}, 4-6 \%$ for $I_{2}$ and 6-10\% higher for $I_{3}$ (Table 2) compared to $\mathrm{D}_{2}$. The seasonal ET values for same irrigation levels and varieties were at par under different dates of sowing but differed significantly with irrigation levels. The variety PBW-343 $\left(\mathrm{V}_{1}\right)$ recorded the highest seasonal ET values under $D_{1}$ sowing for increased levels of irrigations in two out of three years of experimentation followed by K-307 $\left(\mathrm{V}_{2}\right)$ and RSP-561 $\left(\mathrm{V}_{3}\right)$. However, for $D_{2}$ sowing, $V_{2}$ exhibited the maximum seasonal ET values for $I_{2}$ and $I_{3}$ irrigation followed by $\mathrm{V}_{1}$ and $\mathrm{V}_{3}$ respectively. For $\mathrm{I}_{1}$ (one irrigation at CRI), $\mathrm{V}_{2}$ recorded the maximum seasonal ET values followed by $\mathrm{V}_{3}$, but was significantly different from $\mathrm{V}_{1}$ irrespective of sowing dates (Table 2).

\section{Yield and water use efficiency}

Increased application of irrigation significantly increased the yield of the crop. The highest yields coincided with rainfall during vegetative growth (Fig. 1). Lowest yields in the experiment were observed during the second year $(2010-11)$ while the highest yield was recorded in the third year (2011-12) irrespective of irrigation levels (Fig. 2a). The yield increased by $19-31 \%$ and $39-48 \%$ with three and five irrigations respectively compared to $I_{1}$ over both the dates of sowing. Delayed sowing $\left(\mathrm{D}_{2}\right)$ resulted in $10-13 \%$ decrease in yields (across varieties) over all irrigation levels during the experimental period. With three irrigations $\mathrm{V}_{1}$ produced significantly higher yields than $V_{2}$ and $V_{3}$. Under $\mathrm{D}_{2}$ and equivalent irrigation treatments, yields of varieties $V_{1}$ and $V_{2}$ were statistically at par, while $V_{3}$ produced significantly lower yields. Increasing irrigation levels lead to increased seasonal ET values, with the increase depending on the sowing date. Under $\mathrm{D}_{1}, \mathrm{I}_{2}$ and $\mathrm{I}_{3}$ seasonal ET values were 39 and $87 \%$ higher than $I_{1}$ and produced 26 and $43 \%$ higher yields. Under $\mathrm{D}_{2}$ sowing $\mathrm{I}_{2}$ and $\mathrm{I}_{3}$ seasonal ET values were 35 and $76 \%$ higher, with a corresponding 25 and $43 \%$ increase in yield compared to $\mathrm{I}_{1}$.

WUE varied significantly over different irrigation treatments and dates of sowing but was statistically at par among varieties. Under $\mathrm{D}_{1}\left(25^{\text {th }}\right.$ November $), \mathrm{I}_{1}$ had the highest WUE (14.5-14.8 kg ha $\mathrm{mm}^{-1}$ ) followed by $\mathrm{I}_{2}$ $\left(13.1-13.7 \mathrm{~kg} \mathrm{ha}^{-1} \mathrm{~mm}^{-1}\right)$ then $\mathrm{I}_{3}(11.3-11.6$ $\mathrm{kg} \mathrm{ha}^{-1} \mathrm{~mm}^{-1}$ ) (Fig. 2b). However under delayed sowing $\left(\mathrm{D}_{2}, 20^{\text {th }}\right.$ December) the WUE was lower compared to timely sowing, again 
with the highest values under $\mathrm{I}_{1}(13.0-13.1 \mathrm{~kg}$ $\left.\mathrm{ha}^{-1} \mathrm{~mm}^{-1}\right)$ followed by $\mathrm{I}_{2}\left(12.0-12.5 \mathrm{~kg} \mathrm{ha}^{-1}\right.$ $\left.\mathrm{mm}^{-1}\right)$ and $\mathrm{I}_{3}\left(10.7-10.9 \mathrm{~kg} \mathrm{ha}^{-1} \mathrm{~mm}^{-1}\right)$. When averaged over different irrigation levels for a particular date of sowing, WUE values were 9-10\% higher when sown on $\mathrm{D}_{1}$ compared to late sowing on $\mathrm{D}_{2}$. The WUE values under the $\mathrm{D}_{1}-\mathrm{I}_{2}$ treatment $\left(13.1-13.7 \mathrm{~kg} \mathrm{ha}^{-1} \mathrm{~mm}^{-1}\right)$ were closer to that of $\mathrm{D}_{2}-\mathrm{I}_{1}$ treatment $(13.0-13.1 \mathrm{~kg}$ $\mathrm{ha}^{-1} \mathrm{~mm}^{-1}$ ) although they were significantly different (Fig. 2b). As compared to $\mathrm{I}_{1}$ under $\mathrm{D}_{1}$, WUE decreased by $7.8-9.7 \%$ for $\mathrm{I}_{2}$ and by $16.9-22.6 \%$ for $\mathrm{I}_{3}$. Within $\mathrm{D}_{2}$ the reduction in WUE compared to $\mathrm{I}_{1}$ was by $4.3-$ $7.8 \%$ and $16.9-18.3 \%$ under $\mathrm{I}_{2}$ and $\mathrm{I}_{3}$, respectively. The percent reduction in WUE under $I_{2}$ and $I_{3}$ irrigation levels were less for $\mathrm{D}_{2}$ compared to $\mathrm{D}_{1}$ sowing. An increase in irrigation levels from $I_{1}$ to $I_{2}$ lead to $8-10 \%$ decrease in WUE for $\mathrm{D}_{1}$ while the reduction was only $4-8 \%$ for $\mathrm{D}_{2}$. Application of five irrigations $\left(\mathrm{I}_{3}\right)$ lead to a $22 \%$ reduction in WUE for $D_{1}$ while it was only $17 \%$ for $D_{2}$ when compared to $\mathrm{I}_{1}$ (Fig. 2b). The difference in WUE between $\mathrm{D}_{1}$ and $\mathrm{D}_{2}$ was least during 2011-12, due to receipt of rainfall during the vegetative period. This indicates that yield penalty due to delay in planting could be mitigated to some extent by altering the ET requirement through irrigation. The WUE decreased as seasonal ET increased and showed a strong negative relationship with seasonal ET irrespective of dates of sowing indicating that the relationship could be better explained by a non-linear function (Fig. 3).

\section{Evapotranspirational Production Function (ETPF) and Its Relationship with Elasticity of Water Productivity (EWP), Water Use Efficiency (WUE), Marginal Water Use Efficiency (MWUE) and Yield Response Factor (Ky)}

The relationship resulting from regression analysis between grain yield and seasonal ET over three years was best described by a quadratic function (Table 3). Grain yield gradually increased with a corresponding increase in the seasonal ET. However the grain yield response to irrigation varied considerably over different dates of sowing and irrigation levels. The relationship between yield and seasonal ET was found to be a quadratic function where 83 and $88 \%$ of the variation in yield could be explained by variation in seasonal ET under $\mathrm{D}_{1}$ and $\mathrm{D}_{2}$, respectively (Table 3 ). In the equations obtained from regression analyses of $\mathrm{Y}$ and ET it was observed that $\mathrm{Y}$ showed a decreasing trend with increasing seasonal ET and the decrease was higher under $D_{2}$ compared to $\mathrm{D}_{1}$.

The WUE with $\mathrm{I}_{2}$ irrigation under $\mathrm{D}_{1}$ and $\mathrm{I}_{1}$ irrigation under $D_{2}$ were found to be similar, which indicated that with reduced availability of irrigations under delayed sown condition, higher WUE could be maintained with a certain compromise in yield. Three $\left(\mathrm{I}_{2}\right)$ to five $\left(\mathrm{I}_{3}\right)$ irrigations for November sowing $\left(\mathrm{D}_{1}\right)$ gave the highest yields, while under limited irrigation conditions WUE of $14.5-14.7 \mathrm{~kg}$ $\mathrm{ha}^{-1} \mathrm{~mm}^{-1}$ could be achieved with application of single irrigation $\left(\mathrm{I}_{1}\right)$.

For irrigation levels $I_{1}, I_{2}$ and $I_{3}, 47,74$ and $51 \%$ variation in crop yield could be explained due to variation in seasonal ET, respectively (Table 3). Although the WUE increased with decreasing irrigation, marginal water use efficiency (MWUE), was highest for $I_{2}$ and lowest for $I_{3}$ irrigation levels. For each $1 \mathrm{~mm}$ increase in the ET from $I_{1}$ treatment, the MWUE increased from 15 to $18 \mathrm{~kg} \mathrm{ha}{ }^{-1} \mathrm{~mm}^{-1}$ when three irrigations $\left(\mathrm{I}_{2}\right)$ were applied however it declined to $15.2 \mathrm{~kg}$ $\mathrm{ha}^{-1} \mathrm{~mm}^{-1}$ when five irrigations $\left(\mathrm{I}_{3}\right)$ were applied. The yield produced per unit of water input (WUE) was found to be higher under $\mathrm{D}_{1}$ $\left(13.2 \mathrm{~kg} \mathrm{ha}^{-1} \mathrm{~mm}^{-1}\right)$ compared to $\mathrm{D}_{2}(12.0 \mathrm{~kg}$ $\mathrm{ha}^{-1} \mathrm{~mm}^{-1}$ ), however the yield increment per $\mathrm{mm}$ of water input (MWUE) was found to be equal $\left(8 \mathrm{~kg} \mathrm{ha}^{-1}\right)$ under both $\mathrm{D}_{1}$ and $\mathrm{D}_{2}$ sown crops. 
Table.1 Soil physical properties at the experimental site

\begin{tabular}{|c|c|c|c|c|c|c|c|c|c|}
\hline \multirow[t]{2}{*}{ Parameters } & \multicolumn{9}{|c|}{ Soil depth (mm) } \\
\hline & \multicolumn{3}{|c|}{$0-150$} & \multicolumn{2}{|l|}{$150-300$} & $300-450$ & $450-600$ & \multicolumn{2}{|c|}{$600-900$} \\
\hline Bulk density & \multicolumn{3}{|c|}{1.41} & \multicolumn{2}{|l|}{1.46} & 1.51 & 1.56 & \multicolumn{2}{|c|}{1.64} \\
\hline \multicolumn{10}{|c|}{ Soil water retained $\left(\mathrm{m}^{3} \mathrm{~m}^{-3}\right)$ at } \\
\hline $0.01 \mathrm{MPa}$ & & 0.32 & & 0.30 & & 0.28 & 0.26 & 0.22 & \\
\hline \multirow[t]{2}{*}{$1.5 \mathrm{MPa}$} & & 0.12 & & 0.09 & & 0.08 & 0.07 & 0.06 & \\
\hline & \multicolumn{3}{|c|}{ Mechanical composition } & \multicolumn{6}{|c|}{ Chemical properties } \\
\hline Parameters & $\begin{array}{c}\text { Sand } \\
(\%)\end{array}$ & Silt (\%) & Clay $(\%)$ & $\begin{array}{c}\text { Organic C } \\
(\%)\end{array}$ & $\begin{array}{c}\text { Total } \\
\text { Nitrogen } \\
(\%)\end{array}$ & $\begin{array}{l}\text { Available } \\
\text { N (kg/ha) }\end{array}$ & $\underset{(\mathrm{kg} / \mathrm{ha})}{\text { Available } \mathrm{P}_{2} \mathrm{O}_{5}}$ & $\begin{array}{c}\text { Available } \mathrm{K}_{2} \mathrm{O} \\
(\mathrm{kg} / \mathrm{ha})\end{array}$ & $\begin{array}{c}\text { Soil } \\
\text { pH }\end{array}$ \\
\hline Values & 48.5 & 30 & 21.5 & 0.54 & 0.053 & 227.65 & 19.72 & 218.96 & 7.1 \\
\hline
\end{tabular}

Table.2 Response of seasonal evapotranspiration (ET) under different irrigation levels, dates of sowing and varieties. Within a season, values followed by different letters are significantly different atp $<0.05$ according to Tukey Honestly Significant Difference Test

\begin{tabular}{ccccccc}
\hline \multirow{2}{*}{ Treatments } & \multicolumn{2}{c}{$\mathbf{2 0 0 9}-\mathbf{1 0}$} & \multicolumn{2}{c}{$\mathbf{2 0 1 0 - 1 1}$} & \multicolumn{2}{c}{$\mathbf{2 0 1 1}-\mathbf{1 2}$} \\
\cline { 2 - 7 } & $\mathbf{D}_{\mathbf{1}}$ & $\mathbf{D}_{\mathbf{2}}$ & $\mathbf{D}_{\mathbf{1}}$ & $\mathbf{D}_{\mathbf{2}}$ & $\mathbf{D}_{\mathbf{1}}$ & $\mathbf{D}_{\mathbf{2}}$ \\
\hline $\mathbf{I}_{\mathbf{1}} \mathbf{V}_{\mathbf{1}}$ & $163.1^{\mathrm{hi}}$ & $161.5^{\mathrm{i}}$ & $157.6^{\mathrm{i}}$ & $157.8^{\mathrm{i}}$ & $185.8^{\mathrm{f}}$ & $169.8^{\mathrm{g}}$ \\
$\mathbf{I}_{\mathbf{1}} \mathbf{V}_{\mathbf{2}}$ & $180.2^{\mathrm{g}}$ & $174.6^{\mathrm{g}}$ & $170.9^{\mathrm{h}}$ & $171.3^{\mathrm{h}}$ & $185.8^{\mathrm{f}}$ & $179.0^{\mathrm{fg}}$ \\
$\mathbf{I}_{\mathbf{1}} \mathbf{V}_{\mathbf{3}}$ & $178.4^{\mathrm{g}}$ & $172.4^{\mathrm{gh}}$ & $167.9^{\mathrm{hi}}$ & $156.6^{\mathrm{i}}$ & $176.4^{\mathrm{fg}}$ & $190.0^{\mathrm{f}}$ \\
$\mathbf{M e a n}$ & $\mathbf{1 7 3 . 9}$ & $\mathbf{1 6 9 . 5}$ & $\mathbf{1 6 5 . 5}$ & $\mathbf{1 6 1 . 9}$ & $\mathbf{1 8 2 . 7}$ & $\mathbf{1 7 9 . 6}$ \\
$\mathbf{I}_{\mathbf{2}} \mathbf{V}_{\mathbf{1}}$ & $244.9^{\mathrm{e}}$ & $228.1^{\mathrm{f}}$ & $233.7^{\mathrm{e}}$ & $211.9^{\mathrm{f}}$ & $260.0^{\mathrm{d}}$ & $251.4^{\mathrm{d}}$ \\
$\mathbf{I}_{\mathbf{2}} \mathbf{V}_{\mathbf{2}}$ & $238.9^{\mathrm{e}}$ & $248.1^{\mathrm{e}}$ & $235.5^{\mathrm{e}}$ & $233.9^{\mathrm{e}}$ & $247.4^{\mathrm{d}}$ & $260.3^{\mathrm{d}}$ \\
$\mathbf{I}_{\mathbf{2}} \mathbf{V}_{\mathbf{3}}$ & $243.3^{\mathrm{e}}$ & $218.7^{\mathrm{f}}$ & $220.0^{\mathrm{f}}$ & $199.8^{\mathrm{g}}$ & $254.6^{\mathrm{d}}$ & $222.9^{\mathrm{e}}$ \\
$\mathbf{M e a n}$ & $\mathbf{2 4 2 . 4}$ & $\mathbf{2 3 1 . 6}$ & $\mathbf{2 2 9 . 8}$ & $\mathbf{2 1 5 . 2}$ & $\mathbf{2 5 4}$ & $\mathbf{2 4 4 . 9}$ \\
$\mathbf{I}_{\mathbf{3}} \mathbf{V}_{\mathbf{1}}$ & $329.9^{\mathrm{a}}$ & $300.6^{\mathrm{d}}$ & $311.7^{\mathrm{bc}}$ & $287.6^{\mathrm{d}}$ & $331.5^{\mathrm{a}}$ & $290.9^{\mathrm{c}}$ \\
$\mathbf{I}_{\mathbf{3}} \mathbf{V}_{\mathbf{2}}$ & $324.8^{\mathrm{ab}}$ & $309.3^{\mathrm{cd}}$ & $322.4^{\mathrm{ab}}$ & $306.4^{\mathrm{c}}$ & $329.2^{\mathrm{a}}$ & $306.9^{\mathrm{b}}$ \\
$\mathbf{I}_{\mathbf{3}} \mathbf{V}_{\mathbf{3}}$ & $316.4^{\mathrm{bc}}$ & $304.7^{\mathrm{d}}$ & $324.6^{\mathrm{a}}$ & $291.1^{\mathrm{d}}$ & $340.0^{\mathrm{a}}$ & $303.7^{\mathrm{bc}}$ \\
$\mathbf{M e a n}^{\mathbf{c}}$ & $\mathbf{3 2 3 . 7}$ & $\mathbf{3 0 4 . 8}$ & $\mathbf{3 1 9 . 6}$ & $\mathbf{2 9 5}$ & $\mathbf{3 3 3 . 6}$ & $\mathbf{3 0 0 . 5}$ \\
\hline
\end{tabular}

Date of sowing (D) - D1, 25 November; D2, 20 December; Irrigation (I) - I1, 1 irrigation; I2, 3 irrigation; I3, 5 irrigations; Variety (V) - V1, PBW 343; V2, K 307; V3, RSP 561

Table.3 Evapotranspiration production functions under different irrigation regimes and dates of sowing

\begin{tabular}{cccccccccccc}
\hline Treatments & $\begin{array}{c}\text { Evapotranspiration } \\
\text { production functions }\end{array}$ & $\mathbf{R}^{\mathbf{2}} \begin{array}{c}\text { WUE } \\
\left(\mathbf{k g h a}^{-1} \mathbf{m m}^{-\mathbf{1}}\right)\end{array}$ & $\begin{array}{c}\text { MWUE } \\
\left(\mathbf{k g h a}^{-1} \mathbf{m m}^{-\mathbf{1}}\right)\end{array}$ & $\mathbf{E W P}$ & $\mathbf{K y}$ & $\begin{array}{c}\text { ET min ET max } \\
(\mathbf{m m})\end{array}$ & $\begin{array}{c}\text { Ymin } \\
(\mathbf{m m})\end{array}$ & $\begin{array}{c}\text { Ymax } \\
\left(\mathbf{k g h a}^{-1}\right) \\
\left(\mathbf{k g h a}^{-\mathbf{1}}\right)\end{array}$ \\
\hline $\mathbf{I}_{\mathbf{1}}$ & $\mathrm{Y}=-0.187 \mathrm{ET}^{2}+80.21 \mathrm{ET}-5835$ & 0.467 & 14.0 & 15.8 & 1.13 & 3.11 & 176.6 & 214.5 & 2498.6 & 2766.1 \\
$\mathbf{I}_{\mathbf{2}}$ & $\mathrm{Y}=-0.044 \mathrm{ET}^{2}+39.03 \mathrm{ET}-3721$ & 0.744 & 12.8 & 18.2 & 1.43 & 1.75 & 290.8 & 443.5 & 3908.2 & 4934.3 \\
$\mathbf{I}_{\mathbf{3}}$ & $\mathrm{Y}=-0.093 \mathrm{ET}^{2}+73.35 \mathrm{ET}-10355$ & 0.508 & 11.1 & 15.2 & 1.37 & 3.52 & 333.7 & 394.4 & 3765.6 & 4108.0 \\
$\mathbf{D}_{\mathbf{1}}$ & $\mathrm{Y}=-0.028 \mathrm{ET}^{2}+21.71 \mathrm{ET}-371.3$ & 0.829 & 13.2 & 7.9 & 0.57 & 1.10 & 115.2 & 387.7 & 1757.4 & 3837.0 \\
$\mathbf{D}_{\mathbf{2}}$ & $\mathrm{Y}=-0.032 \mathrm{ET}^{2}+22.84 \mathrm{ET}-735.7$ & 0.875 & 12.0 & 7.9 & 0.64 & 1.22 & 151.6 & 356.9 & 1991.8 & 3339.8 \\
\hline
\end{tabular}

Date of sowing (D); Irrigation (I); Variety (V); ET, Evapotranspiration; WUE, Water use efficiency; MWUE, Marginal water use efficiency; EWP, Elasticity of water productivity; Ky, Yield response factor; ETmin, Minimum evapotranspiration; ETmax, Maximum evapotranspiration; Ymin, Minimum yield corresponding to ETmin; Ymax, Maximum yield corresponding to ETmax. 
Fig.1 Weather during the growing seasons of wheat from 2009 to 2012

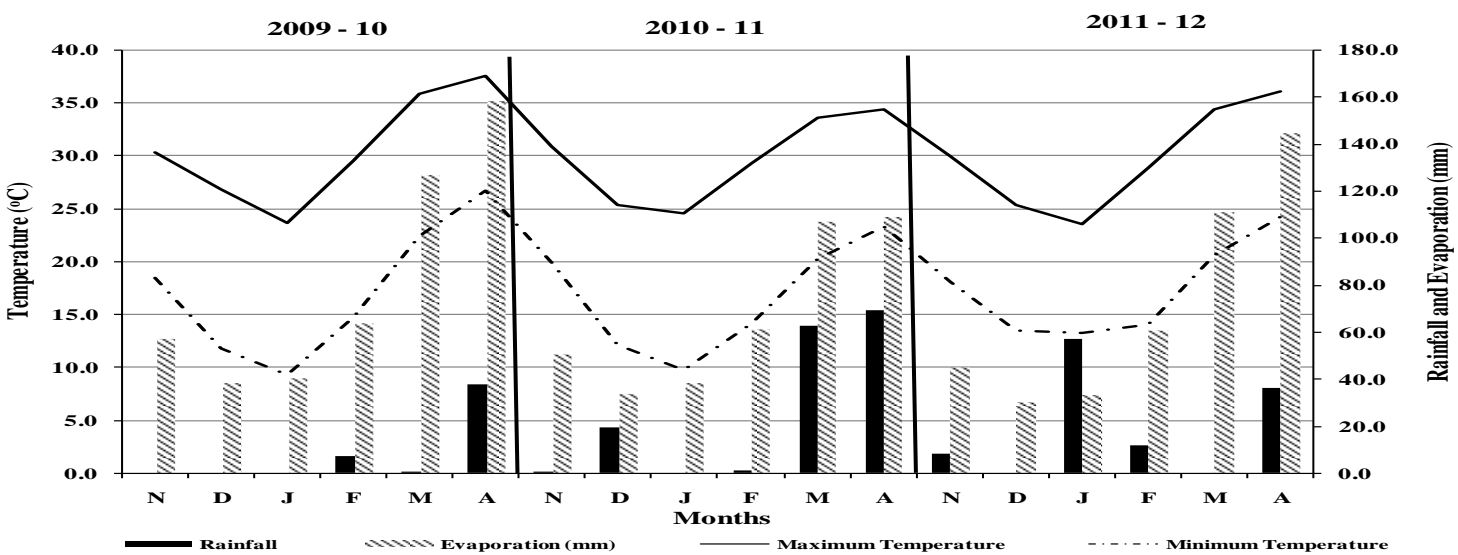

Fig.2 Yield $\left(\mathrm{kg} \mathrm{ha}^{-1}\right)$ (a) and water use efficiency $\left(\mathrm{kg} \mathrm{ha}^{-1} \mathrm{~mm}^{-1}\right)$ (b) of wheat varieties under different irrigation levels and dates of sowing

(a)
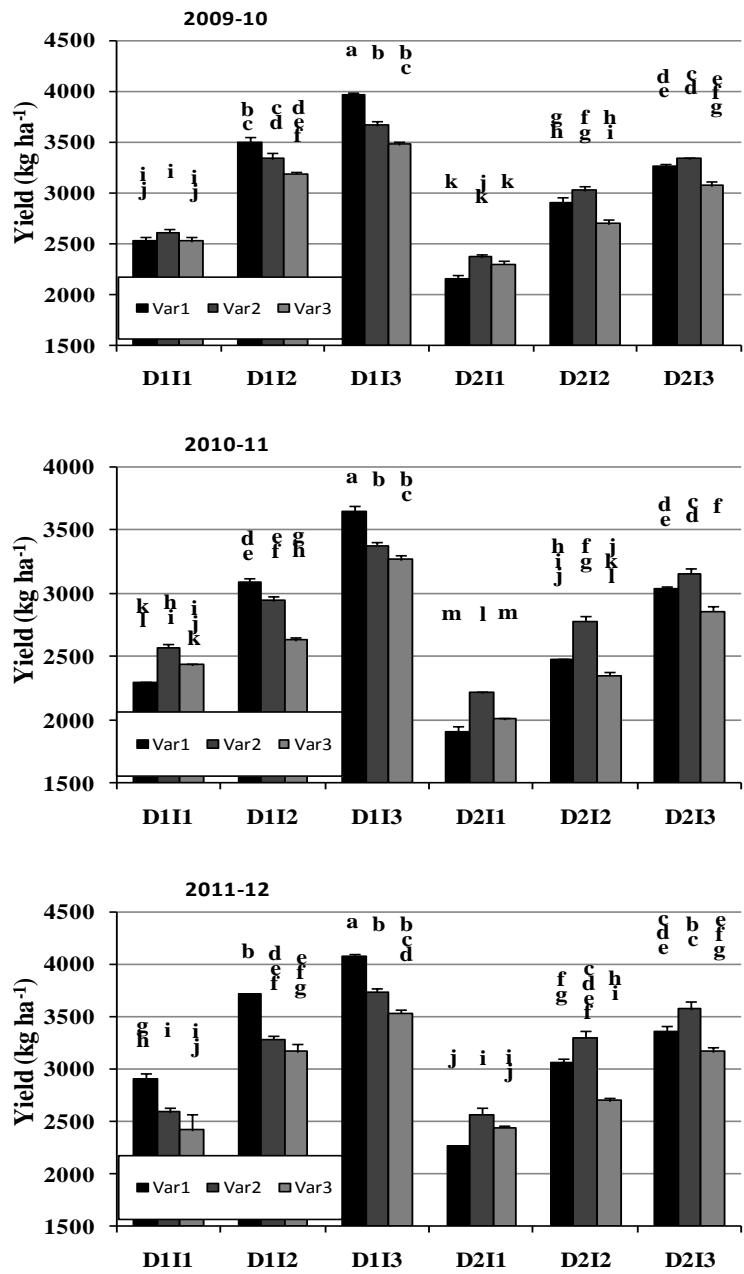

(b)
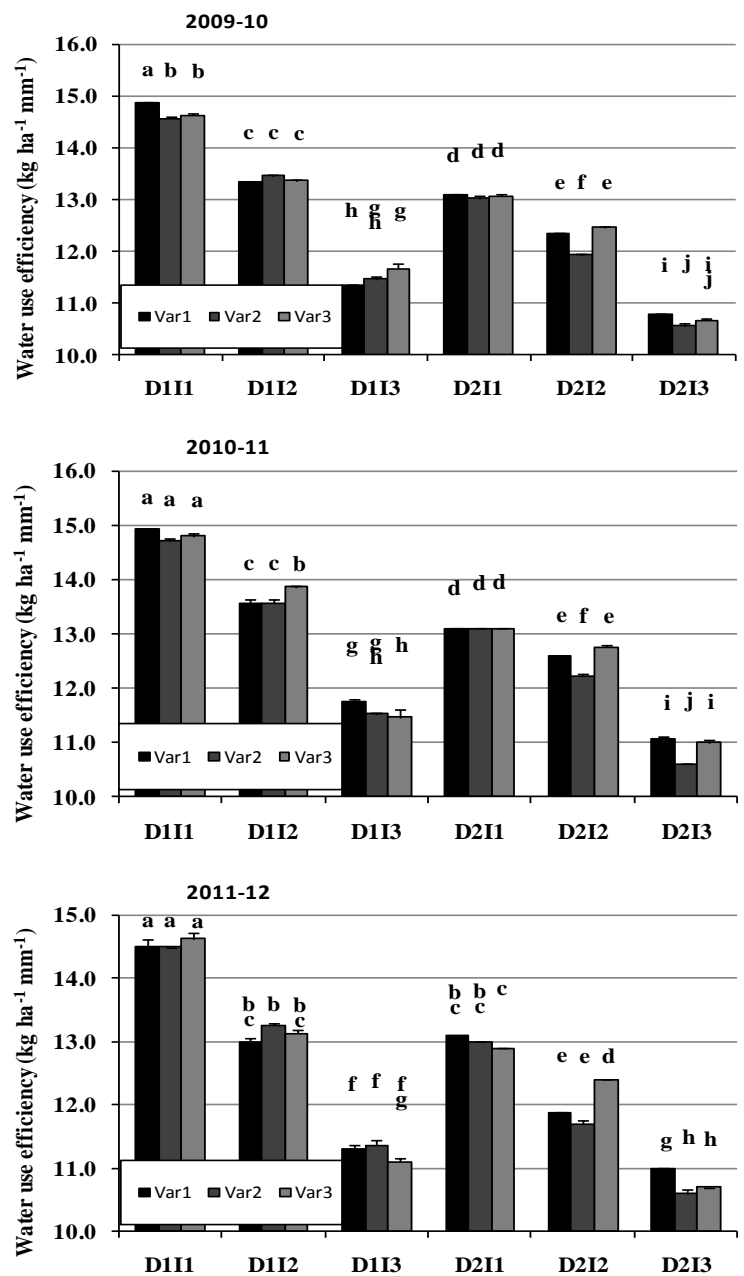

Date of sowing (D); Irrigation (I); Variety (V) - as per Table 2; Within a season, values followed by different letters are significantly different at $\mathrm{p}<0.05$ according to Tukey Honestly Significant Difference Test; Error bars represents the SE of means 
Fig.3 Relations between elasticity of water productivity (EWP), water use efficiency (WUE), marginal water use efficiency (MWUE), yield (Y), and seasonal evapotranspiration (ET) for a quadratic evapotranspiration production function (ETPF) for wheat under different dates of sowing
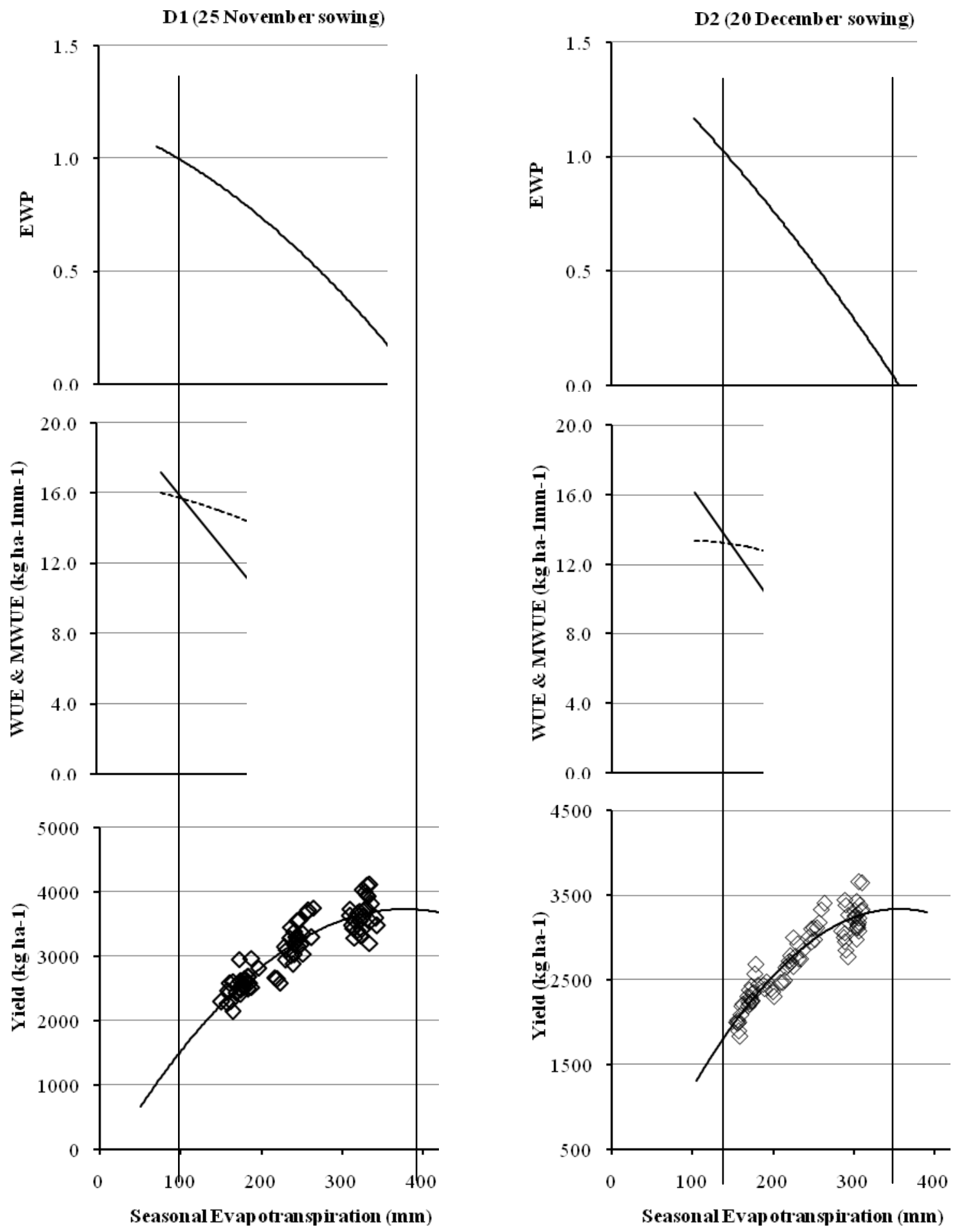
According to (Doorenbos and Kassam 1979) when the EWP = 1, MWUE will be equal to WUE and both will be at their maximum value, while the highest yield will be obtained when $\mathrm{EWP}=0$. The EWP function was greater than 1 under all irrigation treatments (Table 3). Considered over different dates of sowing EWP was greater under $\mathrm{D}_{2}(0.64)$ than $\mathrm{D}_{1}(0.57)$ sowing. The relationship between EWP, MWUE, WUE, Y and ET showed that the highest yield was obtained when the EWP $=0$ while maximum WUE and MWUE was obtained when EWP $=1$, regardless of dates of sowing (Fig. 3). Based on the ETPF, the minimum ET under $\mathrm{D}_{1}$ was estimated to be $115 \mathrm{~mm}$ which could produce $1757 \mathrm{~kg} \mathrm{ha}^{-1}$ grain yield, while for $\mathrm{D}_{2}$ the minimum ET was $151 \mathrm{~mm}$ that could produce $1992 \mathrm{~kg} \mathrm{ha}^{-1}$ yield with maximum WUE (Fig. 3). For maximum yield and ET scenarios, the late sown crop produced $13 \%$ less yield from $8 \%$ reduction in ET compared to timely sown crop. When considered under different irrigation levels the highest EWP was obtained under $\mathrm{I}_{2}(1.43)$ while the lowest was under $\mathrm{I}_{1}$ (1.13). This indicates that under well irrigated situation, a maximum ET of $443 \mathrm{~mm}$ could provide a maximum yield of $4934 \mathrm{~kg}$ $\mathrm{ha}^{-1}$. Simultaneously under dryland or rainfed situation where emphasis in on WUE, ET levels of $177 \mathrm{~mm}$ could provide a minimum yield of $2499 \mathrm{~kg} \mathrm{ha}^{-1}$ (Table 3).

The yield response factor (Ky) was estimated from the ETPF (Doorenbos and Kassam 1979). When considered either over different irrigation levels or under different dates of sowing the value of $\mathrm{Ky}>1$. The maximum value of $\mathrm{Ky}$ (3.52) was obtained under $\mathrm{I}_{3}$ while the lowest was obtained under $I_{2}(1.75)$. The high values of $\mathrm{Ky}$ under $\mathrm{I}_{1}$ corresponded to yield reductions under reduced ET. Under $\mathrm{I}_{3}$ the high Ky value indicates that the yield response to the corresponding water use was not optimum. It was found that Ky was $11 \%$ higher for $D_{2}$ compared to $D_{1}$. These results show that both EWP and Ky were negatively related to seasonal ET.

Irrigation regimes in wheat (Triticum aestivum L.) affected the seasonal ET, yield and WUE of the systems significantly. In similar experiments, Zhang and Oweis (1999) pointed out that ET depends on the seasonal rainfall under rainfed conditions and on the combined amount of water (irrigation and rainfall) under irrigated conditions. The variation observed in seasonal ET was likely due to the variation in canopy volume and atmospheric temperature and reduced growing period. Lower atmospheric temperature correlates with a lower ET demand. The reduced atmospheric temperatures were ultimately reflected in the lower seasonal ET when the crop was sown on $\mathrm{D}_{2}\left(20^{\text {th }}\right.$ December). Ram et al., (2013) also reported greater availability of soil water with five irrigations $\left(\mathrm{I}_{3}\right)$ compared to one $\left(\mathrm{I}_{1}\right)$ and three irrigations $\left(\mathrm{I}_{2}\right)$ increased plant growth and thereby resulted in higher amount of ET losses. The observations are in agreement with the findings of Rathore and Patel (1991) who reported that ET of wheat increased from $240 \mathrm{~mm}$ with 2 irrigations to $460 \mathrm{~mm}$ with five irrigations on clay loam soil in India. In earlier studies Pal et al., (2000) reported that consumption of water varied from $272 \mathrm{~mm}$ with two irrigations (at CRI and boot stage) to $346 \mathrm{~mm}$ with four irrigations (CRI, maximum tillering, boot and milk stages).

With increase in irrigation levels, yield also increased but the rate of increment was not equal with each level of water added (Gaydon et al., 2012). It was also observed that only $13 \%$ yield reduction occurred due to delayed sowing when averaged over irrigation levels during the three years. The maximum yield was produced under five irrigation levels $\left(\mathrm{I}_{3}\right)$ irrespective of the dates of sowing. It can be inferred that for wheat, beyond a certain level 
of yield its increment requires more water input. Other studies have found similar results (Oweis et al., 2000; Zhang et al., 2004). Therefore, by controlling the dates of sowing the water use may be improved with the simultaneous improvement of agricultural practices (Corbeels et al., 1998). Oweis and Hachum (2001) demonstrated that with staggered dates of sowing the peak demand of irrigation water during drought sensitive stages could be avoided and water productivity could be improved over a larger area.

In wheat excessive moisture deficit reduces the time to maturity as well as yield, the detailed study of ET production functions are necessary to quantify the effect of altered dates of sowing and reduced water application on crop yield and WUE. ET is relatively low when water availability is the limiting factor; however under water limiting conditions, increasing ET results in increase in both yield and WUE upto an optimal level. Beyond this optimal ET, the rate of increase on yield and corresponding WUE declined as ET increased. The amount, timing and frequency of irrigation have strong impacts in WUE. Depending on the timing and amount of irrigation, WUE may drop (Nasseri and Fallahi, 2007) or increase (Bandyopadhyay and Mallick 2003) at higher irrigation levels. Results from this study also demonstrated a negative relationship between WUE and seasonal ET. Maurya and Singh (2008) and Ram et al., (2013) also reported a decrease in WUE with an increase in irrigation levels due to proportionately less increase in grain yield with increase in ET. Zhang and Oweis (1999) also observed an increase in grain yield of wheat by $6.8-10.8 \mathrm{~kg} \mathrm{ha}^{-1}$ per mm increase in ET. The WUE was found to decrease with increasing seasonal ET, corroborated by the quadratic nature of ETPF (Liu et al., 2002). The yields of wheat were significantly higher under five irrigations $\left(I_{3}\right)$, although the WUE with three irrigations $\left(\mathrm{I}_{2}\right)$ was either higher or similar to five irrigations $\left(\mathrm{I}_{3}\right)$. Higher efficiency could be achieved not through an increase in yield, but only through reduced irrigation water use which may compensate for the yield reduction (Gaydon et al., 2012). Results suggested that similar wheat yields could be obtained with higher WUE through optimum use of water within different dates of sowing.

The present study also indicates that by using one irrigation at $\mathrm{CRI}\left(\mathrm{I}_{1}\right)$ or three irrigation at CRI, tillering and boot leaf stage $\left(\mathrm{I}_{2}\right)$, yield and WUE can be improved by reducing ET. The fact that maximum ET (ETmax) scenarios obtained under $\mathrm{I}_{2}$ and $\mathrm{I}_{3}$ ETPFs produced the highest yields indicates that increasing ET by 18 and $33 \%$ from the minimum ET (ETmin) obtained under $\mathrm{I}_{3}$ $(333.7 \mathrm{~mm}$ ), would produce 9 and $31 \%$ higher yields respectively. Coventry et al., (2011) reported that wheat grain yield increased in a stepwise manner as additional irrigation was applied. Economization of water helps to conserve water resources where water availability for irrigation is limited.

Among the environmental factors, water deficit during the reproductive phase of development is the most important limiting factor for winter cereals (Blum 2009). If reproductive development is to be successful, it is essential for the plants to maintain their water regime during the generative phase, irrespective of the quantity of biomass achieved during the vegetative phase. This may not be possible with a single irrigation at CRI $\left(\mathrm{I}_{1}\right)$. Both EWP and Ky estimated from the ETPFs for different dates of sowing and irrigation levels achieved highest values when yield and seasonal ET were low and WUE was highest. In contrast, WUE tended to decrease at lower values of EWP and Ky obtaining the maximum yield when EWP $=0$. 
From the ETPFs for dates of sowing it was observed that an increase in $30 \%$ of ETmin $(152 \mathrm{~mm})$ for $\mathrm{D}_{2}$ would provide a yield advantage of $13 \%\left(1992 \mathrm{~kg} \mathrm{ha}^{-1}\right)$ over $\mathrm{D}_{1}$, obtaining the maximum WUE (Table 3). However $388 \mathrm{~mm}$ of seasonal ET under $\mathrm{D}_{1}$ could produce a yield of $3837 \mathrm{~kg} \mathrm{ha}^{-1}$ which was $15 \%$ higher than $\mathrm{D}_{2}$. Estimation of EWP and Ky may be good indicators of the water productivity for varying levels of ET.

The seasonal ET in wheat (Triticum aestivum L.) was higher with a timely sown crop compared to late planting. Maximum seasonal ET values were obtained with higher number of irrigations regardless of planting dates. Under timely sowing, increasing irrigation levels resulted in 39 and $87 \%$ higher seasonal ET and consecutively produced 26 and $43 \%$ higher yields. The timely sowing of wheat resulted in 9-10\% higher WUE compared to late sowing. EWP, Ky and WUE, showed a range of responses to different soil water regimes. In all the cases the yield response factor (Ky) for the crop was observed to be greater than 1 indicating the tendency of the crop towards higher yield reduction with decrease in ET. The wide difference in Ky implied that the relative yield decrease with one irrigation was more compared to three irrigations. Three irrigations appeared to be the breaking point of the yield response curve for a trade-off between yield and water use (ET) for a farmer. MWUE was highest with three irrigations $\left(18.2 \mathrm{~kg} \mathrm{ha}^{-1} \mathrm{~mm}^{-1}\right)$ while dates of sowing did not have an effect. To achieve maximum WUE, the minimum amount of seasonal ET required was lower under timely sowing than required under delayed sowing. Within the different irrigation levels, the lowest values of EWP were obtained with one irrigation under timely sowing. Higher values of EWP under delayed sowing indicated that there is room to increase the yield and WUE of the crop through better irrigation management.
Moreover, as the relative rate of yield deficit was not constant over the range of ET deficit, a non-linear ETPF could better explain the YET relationship compared to a linear ETPF. It can be concluded that under limited water supply in the region, three irrigations are necessary to stabilize the balance between water use and crop productivity. Since the increase in ET reduced the WUE, reduction in irrigation times and amount could be considered as option to improve the water use for the Eastern Gangetic Plains.

\section{References}

Alderfasi, A.A., and Nielsen, D.C. 2001. Use of crop water stress index for monitoring water status and scheduling irrigation in wheat. Agric Water Manag, 47(1): 69-75.

Bandyopadhyay, P., and Mallick, S. 2003. Actual evapotranspiration and crop coefficients of wheat (Triticum aestivum) under varying moisture levels of humid tropical canal command area. Agric Water Manag, 59(1): 33-47.

Blum, A. 2009. Effective use of water (EUW) and not water-use efficiency (WUE) is the target of crop yield improvement under drought stress. Field Crops Res, 112(2): 119-123.

Corbeels, M., Hofman, G., and Van Cleemput, O. 1998. Analysis of water use by wheat grown on a cracking clay soil in a semi-arid Mediterranean environment: weather and nitrogen effects. Agric Water Manag, 38(2): 147167.

Coventry, D. R., Yadav, A., Poswal, R.S., Sharma, R.K., Gupta, R.K., Chhokar, R.S., Gill, S.C., Kumar, V., Kumar, A., Mehta, A., Kleemann, S.G.L., and Cummins, J.A. 2011. Irrigation and nitrogen scheduling as a requirement for optimising wheat yield and quality in 
Haryana, India. Field Crops Res, 123(2): 80-88.

DES 2014. Agricultural statistics at a glance; Directorate of Economics and Statistics, Department of Agriculture and Cooperation, Ministry of Agriculture, Govt. of India, New Delhi.

Directorate of Wheat Research, Karnal 2007. Vision - 2025: DWR perspective Plan.

Doorenbos J., and Kassam, A. 1979. Yield response to water. Irrigation and drainage paper 33: 257.

Gaydon, D.S., Meinke, H., and Rodriguez, D. 2012. The best farm-level irrigation strategy changes seasonally with fluctuating water availability. Agric Water Manag, 103: 33-42.

Gulati, H., and Murty, V. 1979. A model for optimal allocation of canal water based on crop production functions. Agric Water Manag, 2(1): 79-91.

Kang, S., Zhang, L., Liang, Y., Hu, X., Cai, H., and Gu, B. 2002. Effects of limited irrigation on yield and water use efficiency of winter wheat in the Loess Plateau of China. Agric Water Manag, 55(3): 203-216.

Kobata, T., Palta, J.A., and Turner, N.C. 1992. Rate of Development of Postanthesis Water Deficits and Grain Filling of Spring Wheat. Crop Science, 32(5): 1238-1242.

Liu, W., Hunsaker, D., Li, Y., Xie, X., and Wall, G. 2002. Interrelations of yield, evapotranspiration, and water use efficiency from marginal analysis of water production functions. Agric Water Manag, 56(2): 143-151.

Mandal, K.G., Hati, K.M., Misra, A.K., Bandyopadhyay, K.K., and Mohanty, M. 2005. Irrigation and Nutrient Effects on Growth and Water-Yield Relationship of Wheat (Triticum aestivum L.) in Central India. $\mathrm{J}$ of Agronomy and Crop Sci, 191(6): 416425 .
Maurya, R., and Singh, G. 2008. Effect of crop establishment methods and irrigation schedules on economics of wheat (Triticum aestivum) production, moisture depletion pattern, consumptive use and crop water-use efficiency. Indian J of Agric Sci, 78(10): 830-833.

Musick, J.T., Jones, O.R., Stewart, B.A., and Dusek, D.A. 1994. Water-yield relationships for irrigated and dryland wheat in the US Southern Plains. Agron Journal, 86(6): 980-986.

Nasseri, A., and Fallahi, H.A. 2007. Water Use Efficiency of Winter Wheat Under Deficit Irrigation. J of Bio Sci, 7(1): 1926.

Olesen, J.E., Mortensen, J.V., Jørgensen, L.N., and Andersen, M.N. 2000. Irrigation strategy, nitrogen application and fungicide control in winter wheat on a sandy soil. I. Yield, yield components and nitrogen uptake. The $\mathrm{J}$ of Agric Sci, 134(1): 1-11.

Oweis, T., and Hachum, A. 2001. Reducing peak supplemental irrigation demand by extending sowing dates. Agric Water Manag, 50(2): 109-123.

Oweis, T., Zhang, H., and Pala, M. 2000. Water use efficiency of rainfed and irrigated bread wheat in a Mediterranean environment. Agron J, 92(2): 231-238.

Pal, S., Verma, U., Thakur, R., Singh, M., and Upasani, R. 2000. Dry-matter partitioning of late sown wheat under different irrigation schedules. Indian J of Agric Sci, 70(12): 831-834.

Ram, H., Dadhwal, V., Vashist, K.K., and Kaur, H. 2013. Grain yield and water use efficiency of wheat (Triticum aestivum L.) in relation to irrigation levels and rice straw mulching in North West India. Agric Water Manag, 128: 92-101.

Rathore, A., and Patel, S. 1991. Studies on nitrogen and irrigation requirement of 
late sown wheat. Indian $\mathrm{J}$ of Agron 36(2): 184-187.

Saxton, A. 1998. A macro for converting mean separation output to letter groupings in Proc Mixed. Proceedings of the 23rd SAS users group international: 1243-1246.

Singh, P. 1991. Evapotranspiration, evaporation and crop yield relationship for wheat in humid climate. J. Inst. Eng, 77: 65-71.

Sun, H.Y., Liu, C.M., Zhang, X.Y., Shen, Y.J., and Zhang, Y.Q. 2006. Effects of irrigation on water balance, yield and WUE of winter wheat in the North China Plain. Agric Water Manag 85(1): 211-218.
Xue, Q., Zhu, Z., Musick, J.T., Stewart, B.A., and Dusek, D.A. 2006. Physiological mechanisms contributing to the increased water-use efficiency in winter wheat under deficit irrigation. J of Plant Physi, 163(2): 154-164.

Zhang, H., and Oweis, T. 1999. Water-yield relations and optimal irrigation scheduling of wheat in the Mediterranean region. Agric Water Manag, 38(3): 195-211.

Zhang, Y., Kendy, E., Qiang, Y., Changming, L., Yanjun, S., and Hongyong, S. 2004. Effect of soil water deficit on evapotranspiration, crop yield, and water use efficiency in the North China Plain. Agric Water Manag, 64(2): 107122.

\section{How to cite this article:}

Swaraj Kumar Dutta, Pramiti Kumar Chakraborty, Swapan Kumar Mukhopadhyay, Rajib Nath and Prodip Kumar Chakraborty. 2017. Wheat Productivity and Marginal Analysis of Evapotranspiration Production Functions under Deficit Irrigation across Sowing Dates in Eastern India. Int.J.Curr.Microbiol.App.Sci. 6(10): 3458-3471. doi: https://doi.org/10.20546/ijcmas.2017.610.408 